\title{
Fatwa Majelis Ulama Indonesia Tentang Penyelenggaraan Ibadah Dalam Situasi Terjadi Wabah Covid-19 Sebagai Langkah Antisipatif dan Proaktif Persebaran Virus Corona Di Indonesia*
}

\author{
Ahmad Mukri Aji ${ }^{1}$, Diana Mutia Habibaty ${ }^{2}$ \\ Universitas Islam Negeri Syarif Hidayatullah Jakarta \\ $10.15408 /$ sjsbs.v7i8.17059
}

\begin{abstract}
In response to the spread of Covid-19, which reached the Republic of Indonesia, the Indonesian Ulema Council (MUI) released Fatwa Number 14 of 2020 on the application of Worship in a Covid-19 Outbreak situation. This was achieved as a constructive and anticipatory move for the MUI Institute, which serves as a fatwa contributor in Indonesia. This study uses a qualitative research method with a literature approach, especially in the Fatwa section of the Indonesian Ulema Council. The results of this study show that the steps taken by MUI are deemed acceptable as this organization is perceived to have a significant role to play in society. In addition, the measures taken by the Indonesian Ulema Council are aimed at preserving health and preventing exposure to disease. It is important as it is part of preserving the central purpose of religion (al-Dharurat al-Khams).
\end{abstract}

Keywords: Covid-19, Indonesian Ulema Council, Fatwa, Proactive, Anticipatory

\begin{abstract}
Abstrak
Untuk menyikapi persebaran Covid-19 yang telah memasuki Republik Indonesia, Majelis Ulama Indonesia (MUI) mengeluarkan Fatwa No 14 Tahun 2020 Tentang Penyelenggaraan Ibadah dalam Situasi Terjadi Wabah Covid-19. Hal ini dilakukan sebagai langkah proaktif dan antisipatif Lembaga MUI yang berperan sebagai pemberi fatwa di Indonesia. Penelitian ini menggunakan metode penelitian kualitatif dengan pendekatan literatur khususnya pada Fatwa Majelis Ulama Indonesia. Hasil penelitian ini menyatakan bahwa langkah yang dilakukan MUI dianggap tepat karena Lembaga ini dipandang memiliki peran penting di masyarakat. Selain, langkah yang diambil Majelis Ulama Indonesia merupakan upaya menjaga kesehatan dan menghindari dari paparan penyakit. Hal ini penting dilakukan karena merupakan bagian dari menjaga tujuan pokok beragama (al-Dharurat al-Khams).

Kata Kunci: Covid-19, Majelis Ulama Indonesia, Fatwa, Proaktif, Antisipatif
\end{abstract}

\footnotetext{
*Diterima: 14 April 2020, Revisi: 24 Juli 2020, Diterbitkan 12 Agustus 2020.

${ }^{1}$ Ahmad Mukri Aji adalah Dosen Bidang Hukum Islam, Fakultas Syariah dan Hukum, Universitas Islam Negeri Syarif Hidayatullah Jakarta. E-mail: mukri.aji@uinjkt.ac.id.

${ }^{2}$ Diana Mutia Habibaty adalah Dosen Bidang Hukum Ekonomi Syariah, Fakultas Syariah dan Hukum, Universitas Islam Negeri Syarif Hidayatullah Jakarta. E-mail: diana.mutia@uinjkt.ac.id.
} 


\section{A. PENDAHULUAN}

Dunia semakin waspada, virus corona yang menyebabkan penularan Covid-19 diduga pertama kali muncul di Kota Wuhan, Provinsi Hubei, Cina pada pertengahan November 2019. ${ }^{3}$ Sejak saat itu virus ini telah menyebar hampir ke seluruh penjuru bumi tak terkecuali Indonesia. Ia mudah berpindah dan berkembang dari satu tubuh kepada tubuh lainnya dan merenggut banyak korban jiwa. Melihat penularan yang sedemikian masif, World Health Organization (WHO) sebagai Organisasi Kesehatan Dunia yang berada di bawah naungan Perserikatan Bangsa-Bangsa (PBB) telah meningkatkan status covid-19 yang mulanya merupakan wabah menjadi berstatus pandemi. ${ }^{4}$

Di Indonesia, pandemi ini pertama kali terdeteksi pada pertengahan Maret 2020. Ia dapat menular secara mudah melalui tetesan cairan yang berasal dari batuk dan bersin; kontak pribadi seperti melalui sentuhan dan berjabat tangan; menyentuh benda atau permukaan yang telah terkena virus yang kemudian dilanjutkan menyentuh mulut, hidung, maupun mata sebelum mencuci tangan. ${ }^{5}$ Untuk itu dalam rangka mencegah penyebarannya, salah-satu langkah agar dapat memutus rantai penularan virus tersebut adalah dengan menghindari kegiatan yang melibatkan banyak orang. Setiap orang harus menjauhkan dirinya dengan cara melakukan social distancing (menjaga jarak fisik) mereka dari orang-orang sekitarnya dan Pembatasan Sosial Berskala Besar (selanjutnya di singkat PSBB) pada provinsi-provinsi tertentu yang terdampak covid-19 dengan jumlah besar.

Salah-satu kegiatan penting yang dihentikan selama terjadinya penyebaran virus ini adalah kegiatan ibadah yang dilakukan secara berjamaah. Kegiatan sholat wajib dan sholat Jumat yang selalu dilakukan secara berjamaah di masjid dihentikan. Penghentian kegiatan ibadah secara berjama'ah dituangkan dalam Fatwa Majelis Ulama Indonesia Nomor 14 Tahun 2020 Tentang Penyelenggaraan Ibadah dalam Situasi Terjadi Wabah Covid-19.

Fatwa ini dikeluarkan sebagai langkah antisipasi dan wujud sikap proaktif para ulama yang terkumpul dalam Majelis Ulama Indonesia (selanjutnya disingkat MUI). Sebagai alternatif, MUI menganjurkan masyarakat muslim untuk melakukan ibadah di rumah dan mengganti sholat Jumat dengan sholat Dzuhur selama pandemi ini berlangsung.

3 Tempo.co, Infeksi Pertama Virus Corona Diduga Terjadi pada 17 November. Sumber https://dunia.tempo.co/read/1319169/infeksi-pertama-virus-corona-diduga-terjadi-pada-17november/full\&view=ok. Diakses pada 4 April 2020

${ }^{4}$ Pandemi merujuk pada penyakit yang menyebar ke banyak orang di beberapa negara dalam waktu yang bersamaan. Jumlah penyebaran covid-19 sendiri bertambah secara signifkan dan berkelanjutan secara global. LIhat : National Geographic Indonesia, WHO Tetapkan Covid-19 sebagai Pandemi Global, Apa Maksudnya?, Sumber : https://nationalgeographic.grid.id/read/132059249/who-tetapkan-covid-19sebagai-pandemi-global-apa-maksudnya\#. Diakses pada 4 April 2020 pkl. 07.40 WIB.

${ }^{5}$ Kompas.com, Cara Penularan Virus Corona dan Alasan Pentingnya Social Distancing , Sumber : https://www.kompas.com/tren/read/2020/03/19/064600465/cara-penularan-virus-corona-dan-alasanpentingnya-social-distancing. Diakses pada 4 April 2020, pkl. 15.24 WIB 
Kendati demikian, meski munculnya fatwa adalah salah-satu upaya langkah efektif agar penyebaran virus tidak semakin kompleks, ada pula masyarakat yang menyayangkan fatwa ini lahir. Mereka menganggap bahwa beribadah secara berjamaah, khususnya beribadah pada sholat Jumat adalah sikap nyata wujud bakti kepada Allah SWT dan di tengah wabah seperti ini lebih baik mendekatkan diri kepada Sang Pencipta. Landasannya adalah hadist Rasulullah SAW terhadap larangan meninggalkan sholat Jumat, bunyinya: "Siapa yang meninggalkan tiga kali sholat Jumat karena meremehkan, niscaya Allah akan menutup hatinya." (HR Abu Dawud, An-Nasai, dan Ahmad)

Adanya perbedaan respon di masyarakat menyikapi fatwa MUI tentang penyelenggaraan ibadah selama Covid-19 merupakan gambaran dari seberapa berpengaruh MUI pada tatanan masyarakat Indonesia. Apakah peran MUI dalam memberikan fatwa menjadi sedemikian penting pada situasi ini, sedangkan pemerintah di saat yang sama juga telah mengeluarkan imbauan- imbauan dan peraturan terkait Covid-19.

\section{B. METODE PENELITIAN}

Penulis menggunakan metode kualitatif, dimana penelitian kualitatif sering menjadi dasar asumsi penelitian dalam bidang ilmu syariat, ilmu sosial, dan ilmu humaniora. Penelitian kualitatif dimaksudkan untuk membangun pengetahuan melalui penemuan dan pemahaman situasi, termasuk secara tekstual maupun kontekstual. ${ }^{6}$ Metode kualitatif yang menjadi acuan dalam penelitian ini berusaha membuat sebuah gambaran konstruktif, kompleks, laporan terperinci, menganalisis kata perkata dari perspektif beberapa responden maupun eksplorasi studi pada situasi yang berjalan secara alami. ${ }^{7}$

\section{ANALISIS DAN PEMBAHASAN}

\section{Ijtihad sebagai Metode Penemuan Hukum Syariah}

Seluruh penemuan hukum Islam dilakukan dengan metode ijtihad seperti pada penemuan produk fiqih, fatwa, keputusan hakim (qadhi), dan peraturan perundangundangan (qanun). ${ }^{8}$ Fatwa dikeluarkan melalui ijtihad para ulama dalam memecahkan suatu permasalahan yang timbul di masyarakat atau yang dipertanyakan oleh masyarakat itu sendiri. Ijtihad berasal dari kata jahida yang berarti percobaan seseorang pada batas maksimum dan segala daya upaya untuk merealisasikan permasalahan tertentu yang diinginkannya, baik permasalahan yang sudah terjadi dan yang belum terjadi.

\footnotetext{
${ }^{6}$ Rukin, Metodologi Penelitian Kualitatif, (Takalar: Yayasan Ahmar Cendekia Indonesia, cet. 1, 2019), hlm 6-8.

${ }^{7}$ Iskandar, Metodologi Penelitian Kualitatif, (Jakarta: Gaung Persada, cet. 1, 2009), hlm. 11.

${ }^{8}$ Ah. Azharuddin Lathif, Pengantar Fatwa pada Mata Kuliah Praktikum Penyusunan Fatwa
} 
Ijtihad menurut istilah berarti seseorang yang faqih (ahli fiqih) yang mencoba dengan segala daya upayanya untuk menetapkan hukum syariat dengan cara mencari dan menyimpulkan dalil-dalil syar'i. Seorang faqih yang mujtahid adalah seseorang yang dikaruniakan akal yang baik mampu menetapkan hukum syariat yang praktikal berdasarkan dalil-dalil terperinci. ${ }^{9}$

Menurut Imam al-Amidi ijtihad adalah hasil dari curahan segala kemampuan untuk mencari hukum syara yang bersifat dhanni, sampai ia merasa dirinya tidak mampu mencari tamabahan kemampuannya itu. Menurut Syirazi ijtihad adalah kegiatan menghabiskan segenap kekuatan dan kemampuan serta mencurahkan segala daya upaya untuk memperoleh hukum syar'i atau hukum Islam.

Imam Syafi'i menyatakan bahwa seseorang tidak boleh mengatakan tidak tahu terhadap suatu permasalahan apabila ia belum melakukan upaya sunguh-sungguh dalam mencari sumber hukum dalam permasalahan tersebut. ${ }^{10}$ Mayoritas ulama ushul fiqih berpendapat bahwa ijtihad merupakan curahan segenap kemampuan seorang ahli fiqih dalam menemukan pengertian tingkat dhanni terhadap hukum syariat. ${ }^{11}$

Ijtihad dilakukan sebagai salah-satu metode penggali sumber hukum yang berdasarkan al-Qur'an dan sunnah. Ia memiliki beberapa fungsi diantaranya: (a) Fungsi al-ruju' (kembali), maksudnya mengembalikan ajaran-ajaran Islam kepada al-Qur'an dan Sunnah dari segala interpretasi yang kurang relevan; (b) Fungsi al-Ihya (kehidupan),yaitu ijitihad memiliki fungsi menghidupkan kembali bagian-bagian dari nilai Islam agar mampu menjawab sesuai dengan perkembangan zaman; dan (c) Fungsi al-Inabah (pembenahan), artinya ijtihad berfungsi memenuhi kebutuhan terhadap ajaran-ajaran Islam yang telah di-ijtihad-kan ulama terdahulu dan dimungkin tidak sesuai lagi bila melihat konteks zaman dan kondisi yang dihadapi sekarang.

Dengan adanya perkembangan zaman, maka posisi ijtihad menjadi sedemikian penting sebagaimana firman Allah SWT dalam Surat An-Nissa ayat 59:

" Jika kamu mempersengketakan sesuatu maka kembalikanlah sesuatu tersebut kepada Allah dan Rasul-Nya."

Sabda Nabi Muhammad SAW:

"Jika seorang hakim bergegas memutus perkara tentu ia melakukan ijtihad dan bila benar hasil ijtihadnya akan mendapatkan dua pahala. Jika ia bergegas memutus perkara tentu ia melakukan ijtihad dan ternyata hasilnya salah, makai a mendapat satu pahala." (HR. AsySyafi'I dari Amr bin 'Ash).

\footnotetext{
${ }^{9}$ Muhammad Sayyid Tantawi, Konsep Ijtihad dalam Hukum Syarak, Institut Terjemahan Negara Malaysia, Kuala Lumpur, 2009, hal. 2. Judul asli Al-Ijtihad Fil Ahakamu Al-Syariah, Dar Nahdah Mesir, 80 al-Mantiqah al-Sina'iyyah al-Rabi'ah

10 Abd Wafi Has, Ijtihad sebagai Alat Pemecahan Masalah Umat Islam, Jurnal Episteme, Vol.8, No.1, 2013, hal. 89-111

${ }^{11}$ Al-Jurjani Syarief Ali Muhammad, Al-Ta'rifat, Jedddah, la-Haramain, t.t., hal.10
} 
Ijtihad terdiri dari beberapa rukun, seperti : (a) Al-Waqi', yaitu keharusan adanya permasalahan yang sedang atau sudah terjadi atau diduga akan terjadi namun tidak diterngakan oleh nash; (b) Mujtahid, yaitu orang yang melakukan ijtihad dan memounyai kemampuan untuk berijtihad dengan syarat-syarat tertentu; (c) Mujtahid fill, maksudnya hukum syariah yang bersifat amali (taklifi); dan (d) Dalil syara untuk menentukan suatu hukum bagi mujtahid fill.

Secara garis besar al-Ghazali membagi syarat mujtahid pada dua bagian. Pertama, penguasaan terhadap materi hukum terhadap Al-Qur'an dan Sunnah, penguasaan terhadap Bahasa Arab. Kedua, mengetahui nasikh dan mansukh, baik untuk Al-Qur'an dan Sunnah, dan mengetahui metode untuk menyeleksi atau mengklasifikasi Sunnah sebagai sumber. As-Saukani menekankan seorang mujtahid harus memiliki pengetahuan mengenai ushul fiqih dan ilmu nasakh mansukh. Sedangkan menurut AsSyatibi adanya keharusan seorang mujtahid untuk mewujudkan maqasyid syariah dan kemampuan ber istinbath. ${ }^{12}$

Ijtihad dapat dilakukan secara individu (fardi) maupun secara kolektif (jama'i). Ijtihad individu dilaksanakan secara independen (mustaqil) dimana metode, prosedur penetapan hukum, serta proses dalam pengambilan keputusannya dilakukan secara independen. Seperti fatwa-fatwa di kalangan mazhab fiqih, fatwa Yusuf Qardhawi, fatwa Syaikh Ibnu Taimiyah, dan sebagainya. Di Indonesia, ulama yang dikenal sering mengeluarkan fatwa independen ialah Quraisy Shihab.

Yang kedua, ijtihad kolektif, ijtihad ini dilakukan oleh sekelompok mujtahid dengan keahlian yang berbeda-beda dalam berbagai bidang ilmu kemudian bersepakat dalam menjawab suatu permasalahan. ${ }^{13}$ Pada masa kini, ijtihad kolektif lebih sering dilakukan mengingat perkembangan dan permasalahan di dunia yang semakin kompleks sehingga perumusan sebuah fatwa tidak hanya ditempuh dengan mengumpulkan para ahli agama namun juga para cendikiawan pada bidang lainnya.

\section{Fatwa sebagai Bagian dari Produk Ijtihad}

Fatwa secara etimologi berasal dari kata al-fatwa yang merupakan bentuk masdar dari fata, yaftu, fatwan yang bermakna muda, baru penjelasan, penerangan. ${ }^{14}$ Adapula kata afta yang berarti memberikan penjelasan. Kamus Besar Bahasa Indonesia mendefinisikan fatwa sebagai "jawabaan" yang diberikan oleh mufti (pembuat fatwa) terhadap suatu permasalahan.

Secara terminologi fatwa dapat diartikan sebagai al-ifta yang berarti keterangan tentang hukum syara' yang tidak mengikat untuk menerangkan hukum syara' dalam suatu persoalan sebagai jawaban atas pertanyaan yang diajukan oleh penanya yang

\footnotetext{
${ }^{12}$ M. Sulthon, Ijtihad dan Konstektualisasi Hukum Islam, Ar-RIsalah: Media Keislman, Pendidikan dan Hukum Islam, Vol. XVII, No.1, 2019, hal. 71-86

${ }^{13}$ Heri Fadli Wahyudi dan Fajar, Metode Ijtihad Komisi Fatwa Majelis Ulama Indonesia dan Aplikasinya dalam Fatwa, Cakrawala: Jurnal Studi Islam, Vol.13, No.2, 2018, hal. 120-133

${ }^{14}$ Ibnu Mandzur, Lisan al-Arab- Juz XV, Dar Shadir, Beirut, hal. 145
} 
belum mengetahui jawaban atas permasalahannya baik penanya tersebut perorangan maupun kolektif. ${ }^{15}$

Menurut Zamakhsyari fatwa merupakan penjelasan hukum syara' tentang suatu masalah atas pertanyaan seseorang atau kelompok. ${ }^{16}$ Sedangkan As-Syatibi menjelaskan bahwa arti fatwa secara terminologis adalah al-ifta', yaitu keterangan-keterangan tentang hukum syara' yang tidak mengikat untuk diikuti. Yusuf Qardhawi menyatakan bahwa arti fatwa secara istilah adalah menerangkan hukum syara' dalam suatu persoalan sebagai jawaban atas pertanyaan yang diajukan oleh peminta fatwa baik secara perorangan maupun kolektif. ${ }^{17}$

Dari pendapat para ulama dalam mendefinisikan fatwa maka dapat disimpulkan bahwa fatwa merupakan jawaban mufti (pemberi fatwa) atas permasalahan yang dipertanyakan oleh seseorang atau sekelompok orang awam yang tidak mengerti atau tidak menguasai tentang hukum terhadap suatu perbuatan.

Fatwa memiliki rukun sebagai berikut: (a) Istifta, adalah kegiatan dalam menerangkan hukum syara' (fatwa) sebagai upaya untuk menjawab atau menjelaskan hukum dari pertanyaan yang diajukan; (b) Mustafti, yaitu pihak yang meminta fatwa atau pendapat; (c) Mufti, adalah pihak yang diminta pendapatnya; (d) Mustafti fih/isykal, berarti masalah atau pertanyaan yang diajukan kepada mufti;dan (e) Fatwa, yaitu jawaban hukum atas isykal atau pertanyaan yang diajukan.

Dalam merumuskan fatwa, seorang atau sekelompok mufti dapat melakukan beberapa pendekatan yang dikira sesuai dengan problema yang timbul di masyarakat. Pendekatan Fiqih pada fatwa dilakukan dengan cara berikut:18 (a) Pendekatan Fiqih Nusush, yaitu memahami nash-nash syariah baik dalam Al-Qur'an maupun sunnah, sesuai dengan kaidah Bahasa Arab yang baku; (b) Fiqih Maqashid, yaitu melindungi maslahat manusia dengan memenuhi hajatnya dan menghindari mafsadah yang mungkin menimpanya; (c) Fiqih Aulawiyat, yaitu meletakkan setiap urusan (baik hukum, nilai atau perbuatan) secara adil dan proporsional dengan mendahulukan yang lebih penting dari yang penting berdasarkan standar-standar syar'i; (d) Fiqih Muwazanah, yaitu memahami ketentuan Allah dengan menakar mudharat yang lebih ringan; dan (e) Fiqih Taghyir (dakwah), yaitu bagaimana fatwa dan hasil ijtihad itu bisa diterima dan diaplikasikan oleh masyarakat.

${ }^{15}$ Yusuf Qardhawy, al-Fatwa bain al-Indlibath wa al-Tasayyub, Dar al-Qalam, MAsir, hal.5; Lihat juga: Iwan Hermawan, Ushul Fiqh: Metode Kajian Hukum Islam, Kuningan, 2019, hal. 115

${ }^{16}$ Ma'ruf Amin, Fatwa dalam Sistem Hukum Islam, Paramuda Advertising, Jakarta, 2008, hal. 20

${ }^{17}$ Ah. Azharuddin Lathif, Pengantar Fatwa pada Mata Kuliah Praktikum Penyusunan Fatwa

18 Oni Sahroni, Ushul Fikih Muamalah: Kaidah-kiadah dan Ijtihad dan Fatwa dalam Ekonomi Islam, Depok, 2017, hal. 249 


\section{Sejarah Majelis Ulama Indonesia sebagai Lembaga Pembentuk Fatwa}

MUI merupakan Lembaga Swadaya Masyarakat yang mewadahi ulama, zu'ama, dan cendikiawan Islam di Indonesia untuk membimbing, membina dan mengayomi kaum muslim di seluruh Indonesia. Pada awal masa berdirinya yaitu 26 Juli 1975 , MUI didirikan oleh 10 ulama dari unsur ormas Islam yang berbeda, diantaranya Nahdhatul Ulama (NU), Muhammadiyah, Syarikat Islam, Persatuan Tarbiyah Islam (PerTI), AlWashliyah, Math'laul Anwar, Gabungan Usaha Pembaruan Pendidikan Islam (GUPPI), Pendidikan Tinggi Dakwah Islam (PTDI), Dewan Masjid Indonesia (DMI), dan Al Ittihadiyyah, 4 orang ulama dari Dinas Rohani Islam, Angkatan Darat, Angkatan Udara, Angkatan Laut dan POLRI serta 13 orang tokoh yang merupakan tokoh perorangan. ${ }^{19}$

Tujuan didirikan MUI adalah sebagai20; (a) Memberikan bimbingan dan tuntunan kepada umat Islam Indonesia dimana tidak semuanya memiliki pemahaman agama yang mendalam sehingga dengan adanya kehadiran MUI dapat mewujudkan kehidupan beragama dan bermasyarakat yang diridhoi Allah SWT; (b) Memberikan nasihat dan fatwa mengenai masalah keagamaan dan kemasyarakatan kepada pemerintah dan masyarakat, meningkatkan kegiatan bagi terwujudnya ukhwah Islamiyah dan kerukunan antar-umat beragama dalam memantapkan persatuan dan kesatuan bangsa; (c) MUI juga memiliki peran sebagai penghubung antara ulama dan umaro (pemerintah), penterjemah timbal balik antara umat dan pemerintah guna mensukseskan pembangunan nasional; dan terakhir (d) MUI diharapkan dapat meningkatkan hubungan kerjasama antar organisasi, lembaga Islam dan cendikiawan muslim dalam memberikan bimbingan dan tuntunan kepada masyarakat muslim.

Pada dasarnya, MUI memiliki fungsi sebagai pemberi fatwa dan nasihat mengenai permasalahan keagamaan dan kemasyarakatan pada umat Islam Indonesia sebagai perwujudan amar ma'ruf nahi munkar. Dalam pengertian luas, fatwa MUI dapat pula mencakup nasihat, anjuran, dan seruan. Nasihat merupakan keputusan MUI terhadap permasalahan kemasyarakat yang sebaiknya dilakukan oleh masyarakat maupun pemerintah. Sedangkan anjuran merupakan suatu permasalahana kemasyarakatan dimana MUI berpendapat dan mendorong masyarakat agar pelakasanaan terhadap suatu anjuran lebih intensif sehingga tercipta kemaslahatan yang maksimal. ${ }^{21}$

Seiring perkembangannya MUI tidak hanya memberikan fatwa tentang ibadah dan faham keagamaan. Pada tahun 1988 LPPOM MUI dibentuk atas mandat dari pemerintah karena maraknya kasus makanan yang mengandung lemak babi di Indonesia. Untuk itu, dalam rangka memperkuat posisi LPPOM MUI di negara ini maka

${ }_{19}$ Sejarah MUI, Sumber : https://mui.or.id/sejarah-mui/, diakses pada 10 April 2020

${ }^{20} \mathrm{Ibid}$

21 Wahiduddin Adamss, Fatwa MUI dalam Persepktif Hukum dan Perundang-Undangan, Puslitbang Kementrian Agama Republik Indoneisa, hal. 4. Lihat juga Diana Mutia Habibaty, Kedudukan Fatwa Dewan Syariah Nasional-Majelis Ulama Indoneisa Terhadap Hukum Posistif Indonesia, Jurnal Legislasi Indonesia, Vol. 14, No. 4, 2017, hal.447--454 
sejak tahun 1996 ditandatangani nota kesepakatan kerjasama antara Departemen Agama, Departemen Kesehatan, dan MUI dalam menjamin makanan dan produk halal di Indonesia. ${ }^{22}$

Selanjutnya, di akhir tahun 1991 mulai berdiri bank Muamalat sebagai bank syariah pertama di Indonesia menggunakan akad syariah sebagai produk pada lembaga keuangannya. Kemudian mulai bermunculan lembaga keuangan syariah lainnya, seperti reksadana syariah. Untuk membentuk lembaga reksadana syari'ah tersebut maka diadakanlah lokakarya para Ulama yang diselenggarakan oleh MUI Pusat dan direkomendasikan perlunya sebuah Lembaga yang menangani masalah-masalah yang berhubungan dengan Lembaga Keuanga Syariah (LKS). Hingga akhirnya pada April 2000 di Jakarta disahkanlah DSN-MUI. ${ }^{23}$ Dalam perkembangannya Fatwa Dewan Syariah Nasional-Majelis Ulama Indonesia (DSN-MUI) diadopsi oleh Peraturan Bank Indonesia dalam mengeluarkan aturan Bank Indonesia dan Peraturan Otoritas Jasa Keuangan dalam mengeluarkan peraturan terkait perbankan dan jasa keuangannya syariah lainnya. Beberapa fatwa DSN-MUI yang belum diadopsi oleh Undang-Undang terkait Lembaga Keuangan Syariah, Peraturan Bank Indonesia dan Peraturan Otoritas Jasa Keuangan dapat digunakan langsung sebagai pedoman dalam melakukan aktifitas perekonomian syariah dan dapat bersifat mengikat. ${ }^{24}$

\section{Fatwa Majelis Ulama Indonesia sebagai Social Engineering pada Tatanan Negara Republik Indonesia}

Hukum merupakan bagian dari transformasi sosial. Pada kondisi tertentu hukum dipengaruhi oleh masyarakat dan pada sisi yang lain masyarakat dapat mempengaruhi hukum. Para perancang hukum membuat aturan tentu dengan melihat nilai-nilai dimana hukum itu berasal dan bagaimana perilaku masyarakatnya sehingga hukum mengikuti keadaan, lingkungan, dan masyarakat itu sendiri.

Dalam bangunan besar ketatanegaraan Indonesia, terdapat dua macam struktur kenegaraan. Yang pertama adalah suprastruktur, yaitu suatu kehidupan politik pemerintahan yang tampak dari luar. Pada sektor ini terdapat lembaga-lembaga negara yang mempunyai peranan dalam proses kehidupan politik pemerintahan. Suprastruktur ini erat kaitannya dengan lembaga-lembaga negara seperti eksekutif, legislatif, dan yudikatif. Kedua, adalah infrastruktur yaitu berupa kehidupan politik yang tidak tampak dari luar namun nyata dan memiliki dinamikanya sendiri. Infrastruktur berada pada pemberdayaan masyarakat. Pada lini ini terdapat berbagai kekuatan dan persekutuan politik rakyat (masyarakat). Politik rakyat terdiri dari

${ }^{22}$ Sejarah LPPOM MUI, Sumber : http://www.halalmui.org/mui14/main/page/sejarah-lppom-mui, diakses pada 1 Mei 2020, pkl. 12.39 WIB

${ }^{23}$ Sekilas Tentang DSN-MUI, Sumber : https://dsnmui.or.id/kami/sekilas/, diakses pada 1 Mei 2020, pkl. 12.57 WIB

${ }^{24}$ Lihat: Undang-Undang No. 21 Tahun 2008 Tentang Perbankan Syariah 
berbagai macam komponen, seperti Partai Politik, Tokoh Politik, Media Komunikasi Politik, Golongan Kepentingan, dan Golongan Penekan. Golongan Penekan sendiri terdiri atas Lembaga Swadaya Masyarakat (LSM), organisasi-organisasi sosial keagamaan, organisasi kepemudaan, organisasi lingkungan hidup, oragnisasi Pembela Hukum dan HAM, dan Yayasan atau Badan Hukum lainnya. ${ }^{25}$

MUI sebagai organisasi non pemerintah yang merupakan bagian infrastruktur politik negara berasal dari bermacam elemen organisasi sosial keagamaan. Ia terdiri dari ulama-ulama yang mewakili organisasinya. Sesuai dengan perannya sebagai bagian insfrastruktur politik yaitu Lembaga Swadaya Masyarakat ia memiliki andil dalam perkembangan umat Islam di Indonesia. Salah satu tujuan didirikannya MUI sendiri adalah sebagai penghubung antara ulama dan umaro (pemerintah), perannya sebagai penterjemah timbal balik antara umat dan pemerintah dilakukan guna mensukseskan pembangunan nasional.

Fatwa sebagai produk MUI bukan bagian dari peraturan perundang-undangan yang mempunyai kekuatan hukum mengikat yang dapat dipaksakan kepada seluruh rakyat. Fatwa MUI tidak harus ditaati dan tidak ada perlakuan sanksi hukum bagi yang melanggarnya. Legalitas fatwa MUI tidak dapat dipaksakan hingga harus ditaati oleh seluruh masyarakat muslim Indonesia. Namun demikian ia dapat mengikat dan ditaati oleh umat muslim yang memiliki ikatan terhadap MUI itu sendiri. ${ }^{26}$

Ulama merupakan elit yang mempunyai kedudukan sangat terhormat dan berpengaruh besar pada perkembangan masyarakat. Ia mempunyai posisi strategis karena dianggap memiliki pengetahuan yang luas dan mendalam tentang ajaran Islam. Secara teologis ulama juga dipandang sebagai sosok pewaris para Nabi. Maka tidak mengherankan bila ulama menjadi sumber rujukan dari semua aspek kehidupan. ${ }^{27}$ Demikian pula pandangan masyarakat Indonesia terhadap ulama yang tergabung dalam MUI. Bagi umat muslim Indonesia, MUI memiliki kapasitas merumuskan pandangan umum terkait agama Islam dalam tradisi masyarakat muslim melalui fatwafatwa yang dikeluarkannya. Otoritas fatwa itu akan selalu diserahkan kepada ulama karena merekalah yang dipandang memiliki kapasitas dalam melakukan ijtihad. Produk intelektual ulama di bidang hukum telah dijadikan sebagai legitimasi oleh masyarakat dalam menyikapi hubungan anataragama di Indonesia. ${ }^{28}$

${ }^{25}$ Jimly Asshiddique, Format Kelembagaan Negara dan Pergeseran Kekuasaan dalam UUD 1945, Jogjakarta, UUI Pers, 2004, hlm. 72. Lihat juga: Wawan Risnawan, Peran dan Fungsi Infrstruktur Politik dalam Pembentukan Kebijakan Publik, DInamika: Jurnal Ilmiah Ilmu Administrasi Negara, Vol.4 No. 3, 2017, hal. 511-518

${ }^{26}$ Ainun Najib, Fatwa Majelis Ulama Indonesia dalam Perspektif Pembangunan Hukum Responsif, Lisan Al-Hal: Jurnal Pengembangan Pemikiran dan Kebudayaan, Vol. 6, No.2, 2012, hal. 393-404

${ }^{27}$ Mifath Faridh, Peran Sosial Politik Kiyai di Indonesia, Jurnal Sosioteknologi, No 11, Vol.6, 2017

${ }^{28}$ Jeanne Francoise, Pemikiran Politik Islam Modern: Peran Majelis Ulama Indonesia, Prosiding UHAMKA $1^{\text {st }}$ International Conference on Islamic Humanitites and Social Sciences, 23-24 Maret 2017 
Hal tersebut terbukti dengan hasil survei yang dilakukan oleh Lembaga Survei Indonesia (LSI) bersama Indonesia Corruption Warch (ICW) pada 2018 yang memberikan pertanyaan pada 2000 responden. Pada survei tersebut dinyatakan bahwa Majelis Ulama Indonesia merupakan lembaga yang berada pada urutan keempat (sebesar 73\%) yang mendapat kepercayaan oleh masyarakat. Posisi ini berada setelah Komisi Pemberatasan Korupsi atau biasa dikenal KPK sebesar 85\%, Presiden sebesar $84 \%$, dan POLRI mendapat kepercayaan sebesar 75\%. ${ }^{29}$ Dengan demikian dari empat lembaga tersebut, MUI sebagai satu-satunya lembaga non pemerintah yang mendapatkan kepercayaan paling tinggi di masyarakat.

Apa yang mendorong masyarakat Indonesia memiliki atensi dan kepercayaan besar pada MUI? Jawabannya adalah ketaatan masyarakat muslim Indonesia terhadap agamanya. Hasil survei Alvara Research terhadap potret keberagaman muslim Indonesia menyatakan bahwa 95\% masyarakat muslim Indonesia memandang penting peran agama dalam kehidupan sehari-hari. Indikator riset ini diantaranya adalah dari kebiasaan masyarakat menghadiri acara keagamaan, frekuensi menjalankan sholat lima waktu, dan tingkat kesadaran terhadap organisasi kemasyarakatan Islam. ${ }^{30}$ Data ini menunjukkan adanya korelasi antara budaya msyarakat Indonesia dengan nilai-nilai kegamaan dalam Islam. Salah-satu indikator survei seperti kesadaran masyarakat terhadap organisasi kemasyarakatan adalah modal utama dalam mempersatukan masyarakat Indonesia. ${ }^{31}$

Dengan demikian dapat ditarik kesimpulan meskipun fatwa tidak bersifat mengikat namun kepedulian masyarakat terhadap MUI muncul karena kebutuhan masyarakat muslim Indonesia terhadap fatwa telah menjadi tuntutan perkembangan zaman sehingga menyebabkan msyarakat muslim Indonesia secara sukarela mengikatkan diri kepada MUI. Pada implementasinya masyarakat punya saringan tersendiri untuk memilih fatwa mana yang diikuti dan mana yang tidak. ${ }^{32}$

Seperti hadirnya fatwa MUI No. 14 Tahun 2020 tentang Penyelenggaraan Ibadah dalam Situasi Terjadi Wabah Covid-19. MUI mengeluarkan fatwa ini sebagai langkah responsif dan antisipatif dalam merespon masyarakat yang ragu mengambil langkah apa dalam melaksanakan ibadah di tengah pandemi Covid-19.

${ }^{29}$ CNN Indonesia, Survei LSI-ICW: KPK dan Presiden Lembaga Paling Dipercaya. Sumber : https://www.cnnindonesia.com/nasional/20181211070221-20-352621/survei-lsi-icw-kpk-dan-presidenlembaga-paling-dipercaya, diakses pada 4 April 2020 pkl. 07.14 WIB. Lihat juga: Survei: MUI Lembaga NonPemerintah Dipercaya Masyarakat. Sumber : https://mui.or.id/berita/24913/survei-mui-lembaga-nonpemerintah-paling-dipercaya-masyarakat/, diakses pada 4 April 2020 pkl. 17.18 WIB.

30 Tempo.co, Survei Alvara, 95 Persen Muslim Indonesia Religius, Sumber : https://nasional.tempo.co/read/841234/survei-alvara-95-persen-muslim-indonesia-religius/full\&view=ok. Diakses pada 4 April 2020 pkl. 14.47

${ }^{31}$ Muhammad Maulana Hamzah, Peran dan Pengaruh Fatwa MUI dalam Arus Transformasi Sosial Budaya di Indonesia, Millah: Jurnal Studi Agama, Vol. XVII, No. 1, 2017, hal. 127-154

${ }^{32}$ Rumadi Ahmad, Fatwa Hubungan Antaragama di Indonesi: Kajian Kritis tentang Karakteristik, Praktik, dan Implikasinya, Gramesia, Jakarta, 2015, hal.1 


\section{Fatwa Majelis Ulama Indonesia Tentang Penyelenggaraan Ibadah Dalam Situasi Terjadi Wabah Covid-19 Sebagai Langkah Proaktif dan Antisipatif Persebaran Pandemi Pada Tatanan Negara}

Penyelenggaraan ibadah adalah hal yang tidak dapat dipisahkan dari para pemeluk agama. Ia merupakan wujud penghambaan seseorang kepada Tuhannya yang bersifat personal. Dalam Islam ibadah dapat dilakukan secara sendiri-sendiri namun lebih dianjurkan dilakukan secara berjamaah. Untuk ibadah seperti sholat Jumat wajib ( fardu 'ain) dilakukan secara berjama'ah bagi laki-laki dengan minimal jumlah 40 orang yang dapat dilakukan di masjid, lapangan, atau sebuah bangunan yang dapat menampung banyak jama'ah. Hukumnya haram bagi orang yang meninggalkan sholat Jumat tanpa uzur syar'i. ${ }^{33}$

Lahirnya fatwa MUI No. 14 Tahun 2020 tentang Penyelenggaraan Ibadah dalam Situasi Terjadi Wabah Covid-19 merupakan sikap proaktif dan antisipatif MUI dalam melihat situasi Indonesia yang pada saat itu baru saja menyatakan bahwa beberapa orang dari warga negaranya terdampak covid-19. Meskipun merupakan hal baru, langkah yang dilakukan MUI sedemikian startegis karena melihat penyebaran virus corona pada negara-negara lain yang sudah duluan mengalaminya sedemikian cepat dan masif.

Sikap proaktif dan antisipatif MUI sangat beralasan, karena dalam pembuatan fatwa pada MUI terdapat sifat fatwa yang lahir berdasarkan masalahnya, yaitu : ${ }^{34}$ (a) Responsif, artinya permohonan atau pengajuan fatwa berasal dari perorangan, masyarakat, maupun lembaga. Sama dengan dasar terbitnya fatwa pada umumnya ialah karena ada pihak yang bertanya tentang hukum dari suatu perbuatan.; (b) Proaktif, artinya fatwa lahir berdasarkan kejadian aktual di masyarakat yang dinilai berpengaruh pada masalah hukum Islam, rumusan masalah dan pertanyaan atau permohonan yang menjadi dasar terbitnya fatwa ini dapat dari internal MUI; dan (c) Antisipatif, artinya fatwa lahir berdasarkan perkembangan masyarakat yang diduga kuat akan melahirkan permasalahan terkait dengan hukum Islam.

Fatwa No. 14 Tahun 2020 ditandatangani pada 16 Maret 2020 tepat setelah 3 hari pemerintah mengumumkan bahwa persebaran virus corona telah memasuki wilayah Indonesia. Kendati masyarakat Indonesia tidak meminta fatwa kepada MUI dan persebaran virus terbilang baru namun sebagai organisasi perkumpulan ulama yang diperuntukkan menciptakan kemaslahatan umat, MUI mengeluarkan langkah proaktif dan antisipatif dengan mengeluarkan fatwa tersebut.

${ }^{33}$ Hadist Rasulullah : Barangsiapa yang meninggalkan sholat Jumat 3 (tiga) kali tanpa sebab maka Allah akan mengunci mata hatinya (H.R. Malik) ; Lihat juga : Mahmudin Hasibuan, Sholat Jumat, Al-Razi : Jurnal Ilmu Pengetahuan dan Kemasyarakatan, Vol.18, No.2, 2018, hal. 1-13

${ }^{34}$ Asrorun Ni'am Sholeh, Prosedur dan Metode Fatwa Majelis Ulama Indonesia, Disampaikan dalam Bimbingan Teknis Perumudan Fatwa Kerjasama Komisi Fatwa MUI dan Fakultas Syariah dan Hukum UIN Syarif Hidayatullah Jakarta, Jakarta, 15 Mei 2018 
Asrorun Ni'am selaku Sekretaris MUI menyatakan bahwa Sholat Jumat merupakan hal wajib namun dalam situasi wabah ini (ketika lahirnya fatwa, status covid-19 belum mencapai pandemi) ikhtiar dalam melindungi jiwa dan kesehatan juga kewajiban manusia sehingga kewajiban sholat Juma'at dan kewajiban melindungi diri tidak dapat dibenturkan. Menurutnya menjaga kesehatan dan menjauhi diri dari paparan penyakit merupakan bagian dari menjaga tujuan pokok beragama (al-Dharurat al-Khams). ${ }^{35}$

Pada Fatwa No. 14 Tahun 2020 dikatakan bahwa sholat Jumat dapat dilaksanakan bila disuatu kawasan potensi penularannya rendah berdasarkan ketetapan pihak berwenang yang dalam hal ini pemerintah. Namun sholat Jumat boleh ditinggalkan dan diganti dengan sholat Jumat dirumah bila dalam suatu kawasan potensi penularan tinggi atau sangat tinggi. ${ }^{36}$

Untuk itu karena ibadah sholat Jumat yang dinilai wajib dilaksanakan secara berjamaah direkomendasikan dihentikan selama pandemi berlangsung maka untuk ibadah berjamaah lainnya yang bersifat anjurannya pun dihentikan sampai kawasannya dianggap memiliki potensi penularan yang rendah. ${ }^{37}$ Hingga terakhir tulisan ini dibuat pandemi masih terus saja berlanjut bahkan belum terlihat ada penurunan kasus.

\section{KESIMPULAN}

Fatwa No. 14 Tahun 2020 tentang Penyelenggaraan Ibadah dalam Situasi Terjadi Wabah Covid-19 lahir merupakan bagian dari langkah proaktif dan antisipatif MUI dalam menanggapi persebaran virus yang telah sampai di Indonesia. Seperti fatwa pada umumnya, fatwa ini bukan berasal dari pertanyaan masyarakat karena dalam pembuatan fatwa sendiri terdapat 3 macam cara, yaitu: responsif, proaktif, dan antisipatif.

Dalam penyelenggaraan ibadah berjamaah, MUI merekomendasikan untuk meniadakan sementara segala macam bentuk peribadatan di masjid, termasuk sholat Jumat. Hal ini dilakukan karena menurut MUI menjaga kesehatan dan menjauhi diri dari paparan penyakit merupakan bagian dari menjaga tujuan pokok beragama (alDharurat al-Khams).

\section{Referensi}

Adams, Wahiduddin. Fatwa MUI dalam Persepktif Hukum dan Perundang-Undangan, Puslitbang Kementrian Agama Republik Indonesia.

\footnotetext{
${ }^{35}$ Kompas TV, Fatwa MUI: Umat Islam Diperbolehkan Tidak Salat Jumat karena Virus Corona, Sumber : https://www.youtube.com/watch?v=LLGAjQ4pais

${ }^{36}$ Fatwa MUI No 14 Tahun 2020 tentang Penyelenggaraan Ibadah dalam Situasi Terjadi Wabah Covid-19

${ }^{37}$ Fatwa MUI No 14 Tahun 2020 tentang Penyelenggaraan Ibadah dalam Situasi Terjadi Wabah Covid-19
} 
Ahmad, Rumadi. (2015). Fatwa Hubungan Antaragama di Indonesia: Kajian Kritis tentang Karakteristik, Praktik, dan Implikasinya. Jakarta: Gramedia.

Amin, Ma'ruf. (2008). Fatwa dalam Sistem Hukum Islam, Jakarta: Paramuda Advertising.

Asshiddique, Jimly. (2004). Format Kelembagaan Negara dan Pergeseran Kekuasaan dalam UUD 1945. Jogjakarta: UUI Pers.

Faridh, Mifath. (2017) Peran Sosial Politik Kiyai di Indonesia. Jurnal Sosioteknologi, 11(6).

Fatwa MUI No 14 Tahun 2020 tentang Penyelenggaraan Ibadah dalam Situasi Terjadi Wabah Covid-19

Francoise, Jeanne. (23-24 Maret 2017). Pemikiran Politik Islam Modern: Peran Majelis Ulama Indonesia, Prosiding UHAMKA $1^{\text {st }}$ International Conference on Islamic Humanitites and Social Sciences.

Habibaty, Diana Mutia. (2017). Kedudukan Fatwa Dewan Syariah Nasional-Majelis Ulama Indoneisa Terhadap Hukum Posistif Indonesia. Jurnal Legislasi Indonesia, 1 4(4): 447-454

Hamzah, Muhammad Maulana. (2017). Peran dan Pengaruh Fatwa MUI dalam Arus Transformasi Sosial Budaya di Indonesia. Millah: Jurnal Studi Agama, 17 (1) : 127154

Has, Abd Wafi. (2013). Ijtihad sebagai Alat Pemecahan Masalah Umat Islam, Jurnal Episteme, 8(1): 89-111

Hasibuan, Mahmudin. (2018). Sholat Jumat, Al-Razi : Jurnal Ilmu Pengetahuan dan Kemasyarakatan. 18 (2): 1-13

Hermawan, Iwan. (2019). Ushul Fiqh: Metode Kajian Hukum Islam, Kuningan: Hidayatul Qur'an.

Lathif, Ah. Azharuddin. (2019). Pengantar Fatwa pada Mata Kuliah Praktikum Penyusunan Fatwa, Fakultas Syariah dan Hukum UIN Syarif Hidayatullah Jakarta.

Tantawi, Muhammad Sayyid. (2009). Konsep Ijtihad dalam Hukum Syarak. Kuala Lumpur: Institut Terjemahan Negara Malaysia.

Muhammad, Al-Jurjani Syarief Ali. (tanpa tahun). Al-Ta'rifat, Jedddah: Al-Haramain.

Qardhawy. (tanpa tahun). Yusuf al-Fatwa bain al-Indlibath wa al-Tasayyub, Mesir: Dar alQalam.

Sulthon, M. (2019). Ijtihad dan Konstektualisasi Hukum Islam. Ar-Risalah: Media Keislman, Pendidikan dan Hukum Islam, 17(1): 71-86

Wahyudi, Heri Fadli dan Fajar. (2018). Metode Ijtihad Komisi Fatwa Majelis Ulama Indonesia dan Aplikasinya dalam Fatwa, Cakrawala : Jurnal Studi Islam. 13 (2): 120133

Mandzur, Ibnu. (tanpa tahun). Lisan al-Arab-Juz XV. Beirut: Dar Shadir. 
Najib, Ainun. (2012). Fatwa Majelis Ulama Indonesia dalam Perspektif Pembangunan Hukum Responsif, Lisan Al-Hal : Jurnal Pengembangan Pemikiran dan Kebudayaan. 6 (2): 393-404

Risnawan, Wawan. (2017). Peran dan Fungsi Infrstruktur Politik dalam Pembentukan Kebijakan Publik. Dinamika: Jurnal Ilmiah Ilmu Administrasi Negara. 4 (3): 511-518

Sahroni, Oni. (2017). Ushul Fikih Muamalah: Kaidah-kiadah dan Ijtihad dan Fatwa dalam Ekonomi Islam, Depok: Rajawali Pers.

Sholeh, Asrorun Ni'am. (15 Mei 2018). Prosedur dan Metode Fatwa Majelis Ulama Indonesia, disampaikan dalam Bimbingan Teknis Perumudan Fatwa Kerjasama Komisi Fatwa MUI dan Fakultas Syariah dan Hukum UIN Syarif Hidayatullah Jakarta.

Undang-Undang No. 21 Tahun 2008 Tentang Perbankan Syariah

\section{WEBSITE}

CNN Indonesia, Survei LSI-ICW: KPK dan Presiden Lembaga Paling Dipercaya. Sumber: $\quad$ https://www.cnnindonesia.com/nasional/20181211070221-20352621/survei-lsi-icw-kpk-dan-presiden-lembaga-paling-dipercaya, diakses pada 4 April 2020 pkl. 07.14 WIB.

Kompas.com, Cara Penularan Virus Corona dan Alasan Pentingnya Social Distancing , Sumber: $\quad$ https://www.kompas.com/tren/read/2020/03/19/064600465/carapenularan-virus-corona-dan-alasan-pentingnya-social-distancing. Diakses pada 4 April 2020, pkl. 15.24 WIB

Kompas TV, Fatwa MUI: Umat Islam Diperbolehkan Tidak Salat Jumat karena Virus Corona, Sumber : https://www.youtube.com/watch?v=LLGAjQ4pais

MUI Lembaga Non-Pemerintah Dipercaya Masyarakat. Sumber : https://mui.or.id/berita/24913/survei-mui-lembaga-non-pemerintah-palingdipercaya-masyarakat/, diakses pada 4 April 2020 pkl. 17.18 WIB.

National Geographic Indonesia, WHO Tetapkan Covid-19 sebagai Pandemi Global, Apa Maksudnya?, Sumber : https://nationalgeographic.grid.id/read/132059249/whotetapkan-covid-19-sebagai-pandemi-global-apa-maksudnya\#. Diakses pada 4 April 2020 pkl. 07.40 WIB.

Sejarah MUI, Sumber : https://mui.or.id/sejarah-mui/, diakses pada 10 April 2020

Sejarah LPPOM MUI, Sumber : http://www.halalmui.org/mui14/main/page/sejarahlppom-mui, diakses pada 1 Mei 2020, pkl. 12.39 WIB

Sekilas Tentang DSN-MUI, Sumber : https://dsnmui.or.id/kami/sekilas/, diakses pada 1 Mei 2020, pkl. 12.57 WIB

Tempo.co, Infeksi Pertama Virus Corona Diduga Terjadi pada 17 November. Sumber https://dunia.tempo.co/read/1319169/infeksi-pertama-virus-corona-didugaterjadi-pada-17-november/full\&view=ok. Diakses pada 4 April 2020

Tempo.co, Survei Alvara, 95 Persen Muslim Indonesia Religius, Sumber : https://nasional.tempo.co/read/841234/survei-alvara-95-persen-muslimindonesia-religius/full\&view=ok. Diakses pada 4 April 2020 pkl. 14.47 